\title{
PENGEMBANGAN MODUL BERBASIS INQUIRY LAB PADA MATERI SISTEM GERAK UNTUK MENINGKATKAN HASIL BELAJAR SISWA KELAS XI SMAN 1 MEJAYAN
}

\author{
Andrias Marstanto Setyo Pranoto ${ }^{1}$, Sajidan $^{2}$, dan Baskoro Adi Prayitno ${ }^{3}$ \\ ${ }^{1}$ Program Studi Magister Pendidikan Sains FKIP Universitas Sebelas Maret \\ Surakarta, 57126, Indonesia \\ andrias_setyo@yahoo.co.id \\ ${ }^{2}$ Program Studi Magister Pendidikan Sains FKIP Universitas Sebelas Maret \\ Surakarta, 57126, Indonesia \\ sajidan@fkip.uns.ac.id \\ ${ }^{3}$ Program Studi Magister Pendidikan Sains FKIP Universitas Sebelas Maret \\ Surakarta, 57126, Indonesia \\ baskoro_ap@fkip.uns.ac.id
}

\begin{abstract}
Abstrak
Penelitian ini bertujuan untuk 1) mengembangkan modul berbasis Inquiry Lab untuk meningkatkan hasil belajar siswa pada materi sistem gerak, 2) menguji kelayakan modul berbasis Inquiry Lab untuk meningkatkan hasil belajar siswa pada materi sistem gerak, 3) menguji keefektivan modul berbasis Inquiry Lab untuk meningkatkan hasil belajar siswa pada materi sistem gerak di SMA Negeri 1 Mejayan. Pengembangan modul berbasis Inquiry Lab mengacu pada 9 langkah model Research and development (R\&D) dari Borg and Gall (1983) meliputi: 1) penelitian dan pengumpulan data, 2) perencanaan, 3) pengembangan produk, 4) uji coba produk awal, 5) revisi produk I, 6) uji coba lapangan, 7) revisi produk II, 8) uji coba lapangan operasional, 9) revisi produk akhir. Analisis hasil penelitian menggunakan dua teknik yaitu deskriptif kualitatif dan deskriptif kuantitatif (suwastono, 2011). Hasil penelitian menunjukkan: a) Karakteristik Modul Biologi Inquiry Lab pada Materi Sistem Gerak yang dikembangkan menggunakan sintak Inquiry Lab, meliputi observasi, manipulasi, generalisasi, verifikasi dan aplikasi. Setiap kegiatan pembelajaran siswa di arahkan untuk menemukan konsep melalui aktivitas laboratorium, b) Kelayakan modul berbasis Inquiry Lab sebagai berikut: a) Uji validasi ahli materi 93,00\% dengan kualifikasi sangat baik, b) Validasi ahli pengembangan desain $82,90 \%$ dengan kualifikasi sangat baik, c) Validasi ahli perangkat 95,70\% dengan kualifikasi sangat baik, d) Uji kelompok kecil pengguna lapangan (guru dan siswa), validator praktisi (guru) 92,00\% dengan kualifikasi sangat baik, e) Uji lapangan terbatas 83,82\% dengan kualifikasi sangat baik. 3) Keefektifan Modul Biologi berbasis Inquiry Lab pada materi sistem gerak efektif dalam meningkatkan hasil belajar siswa karena menunjukkan adanya perbedaan hasil posttest antara kelas modul berbasis Inquiry Lab dan kelas modul sekolah dengan nilai Sig. $=0.000<$ $\alpha=0.05$
\end{abstract}

Kata Kunci: Modul, Inquiry Lab, Hasil Belajar

\section{Pendahuluan}

Tantangan di era pengetahuan yang semakin dinamis, berkembang, dan semakin maju memerlukan sumber daya manusia yang memiliki keterampilan intelektual tingkat tinggi Galbreath (1999) Keterampilan intelektual tinggi ditandai kemampuan penalaran yang logis, sistematis, kritis, cermat, dan kreatif serta memiliki kompetensi sikap yang baik dalam mengkomuni- kasikan gagasan dan memecahkan masalah. Kemampuankemampuan yang membekali intelektual peserta didik tersebut dapat dikembangkan melalui pendidikan. Pada era pengetahuan, modal intelektual, khususnya kecakapan berpikir tingkat tinggi (higher order thinking) merupakan kebutuhan sebagai 
tenaga kerja yang andal di abad 21(Snyder dan Snyder, 2008).

Pembelajaran sains pada hakikatnya terdiri atas produk, proses, dan sikap yang menuntut siswa melakukan penemuan dan pemecahan masalah. Sains memiliki fungsi yang strategis karena dapat dipergunakan untuk mengembangkan potensi dan kemampuan-kemampuan siswa baik aspek kognitif, psikomotorik, maupun afektif (Mundilarto, 2005). Hasil belajar merupakan salah satu tujuan proses pembelajaran. Merujuk pada Anderson \& Krathwol (2010) menyatakan bahwa hasil belajar mencakup tiga ranah yaitu kognitif, psikomotorik, dan afektif.

Kemampuan intelektual siswa menjadi tolak ukur keberhasilan dalam proses pembelajaran pada ranah kognitif. Ranah kognitif memiliki enam indikator jenjang kognitif yaitu kemampuan mengingat (remember), memahami (understand), menerapkan (apply), menganalisis (analyze), mengevaluasi (evaluation), dan mencipta (create). Keterampilan motorik siswa menjadi tolak ukur keberhasilan dalam proses pembelajaran pada ranah psikomotor. Ranah psikomotor terindikasi melalui lima indikator meliputi pengenalan (initiation), manipulasi (manipulation), ketelitian (precision), artikulasi (articulation), dan naturalisasi (naturalization). Sikap siswa menjadi tolak ukur keberhasilan dalam proses pembelajaran pada ranah afektif. Ranah afektif terindikasi melalui lima kriteria meliputi sikap menerima (receive), memberikan respon (respond), memberikan nilai (value), konseptualisasi nilai (conseptualize value), dan internalisasi nilai (internalize value). (Sungkono, 2013)

Tinggi rendahnya kemampuan siswa berpengaruh terhadap hasil belajar. Hal ini senada dengan penelitian yang dilakukan oleh Nursanti (2014) bahwa Inquiry Lab dapat meningkatkan hasil belajar peserta didik. berdasarkan hasil Ujian Nasional (UN) 2013/2014 menunjukkan persentase penguasaan soal materi sistem gerak manusia SMA Negeri 1 Mejayan baru mencapai 49,09, untuk tingkat Kota nilainya 55,95 , dan untuk tingkat provinsi 33,97, (BSNP, 2013).

Hasil observasi analisis 8 Standar Nasional Pendidikan (SNP) di SMA Negeri 1 Mejayan yang meliputi standar isi, standar proses, standar kompetensi lulusan, standar pendidik dan tenaga kependidikan, standar sarana dan prasarana, standar pengelolaan, standar pembiayaan dan standar penilaian diperoleh gap antara skor ideal dan skor ketercapaian sebesar 12,78 $\%$. Skor gap tersebut berasal dar beberapa komponen SNP yang memperoleh skor 1 dan 2. Komponen standar proses memiliki gap $2.77 \%$. Standar proses berkaitan dengan aktifitas antara peserta didik dengan pendidik serta lingkunganya selama proses pembelajaran. Rendahnya standar proses dipengaruhi oleh kurang optimalnya proses pembelajaran yang berlangsung di dalam kelas.

Hasil wawancara dengan siswa menggunakan kuesioner diketahui bahwa guru menggunakan metode ceramah, sehingga hal ini menyebabkan kurangnya motivasi siswa untuk mengikuti pembelajaran Biologi. Permasalan lain yang sering terjadi adalah kurangnya perhatian siswa terhadap materi yang disampaikan oleh guru. Hal ini karena siswa mengalami kesulitan dalam mempelajari materi-materi Biologi yang bersifat abstrak dan siswa juga sering lupa terhadap materi yang telah disampaikan oleh guru, sehingga hal ini menjadi masalah yang serius bagi sekolah khususnya para guru yang mengajar disana. Hal ini diperkuat dengan nilai mid semester siswa tahun pelajaran 2013/2014 yang dirangkum pada Tabel 1.1

Tabel 1.1 Ketuntasan Belajar Siswa Pada Materi

Sistem Gerak Pada Manusia Tahun Pelajaran 2013/2014

\begin{tabular}{lccc}
\hline Kelas & Jumlah Siswa & $\begin{array}{c}\text { Tuntas } \\
(\boldsymbol{\%})\end{array}$ & $\begin{array}{c}\text { Tidak } \\
\text { Tuntas } \\
(\boldsymbol{\%})\end{array}$ \\
\hline XIIPA1 $^{1}$ & 34 & 68 & 32 \\
\hline XIIPA $^{2}$ & 35 & 64 & 36 \\
\hline XIIPA $^{3}$ & 35 & 64 & 34 \\
\hline
\end{tabular}

(Sumber: Dokumen SMA Negeri 1 Mejayan 2014) 
Berdasarkan analisis buku ajar di sekolah SMA Negeri 1 Mejayan diperoleh aspek pada indikator hasil belajar yang mencakup tiga ranah hasil belajar yaitu ranah pengetahuan, sikap, dan keterampilan. Ranah pengetahuan menunjukan sebesar $18.51 \%$, sikap sebesar $22.22 \%$, dan ranah keterampilan sebesar $11.11 \%$. Dapat disimpulkan bahwa buku ajar yang digunakan disekolah SMA Negeri 1 Mejayan yang menggunakan indikator hasil belajar belum optimal meningkatkan hasil belajar siswa

Pembelajaran berbasis inkuiri laboratorium menekankan pada aktivitas dalam membantu siswa belajar dan memahami proses dan keterampilan berpikir layaknya ilmuan dan memahami karakteristik penelitian ilmiah (Wenning, 2010 \& Khan, et al., 2011). Model pembelajaran inkuiri laboratorium memiliki sejumlah langkah termasuk aktif mengidentifikasi suatu topik atau masalah, menghasilkan pertanyaan yang akan diteliti, menyelidiki masalah dengan melakukan penelitian yang relevan, berpikir kritis tentang masalah yang akan dipecahkan, menjawab pertanyaan yang diajukan, menarik kesimpulan dan merefleksikan pada proses penyelidikan (Vajoczki, S. et al., 2011).

Modul merupakan solusi untuk permasalahan bahan ajar di SMA Negeri 1

Mejayan karena memuat serangkaian kegiatan sistematis yang dapat dipelajari melalui instruksi dan praktek yang dirancang secara khusus. Modul yang berpotensi dapat meningkatkan hasil belajar adalah modul yang dilengkapi dengan rangkaian kegiatan siswa untuk memecahkan permasalahan berdasarkan fakta yang ditemukan untuk mendapatkan pemahaman konseptual, salah satunya yang mengintegrasikan aktifitas pembelajaran pembelajaran ke dalam modul (Rusche \& Jason, 2011).

Hal ini senada dengan penelitian yang dilakukan oleh swiden (2013), Mundilarto (2010) menunjukan bahwa model pembelajaran Inquiry $L a b$ dapat meningkatkan motivasi dan prestasi belajar peserta didik, serta hasil penelitian Adam (2011) dan Tajudin (2013). menunjukan bahwa model pembelajaran Inquiry Lab dapat meningkatkan hasil belajar dan pemahaman sains peserta didik. Penelitian ini bertujuan: 1) Menyusun produk pengembangan modul Biologi berbasis Inquiry Lab materi Sistem Gerak manusia; 2) Mengetahui kelayakan modul Biologi berbasis Inquiry Lab materi Sistem Gerak manusia; 3) Mengetahui efektivitas modul Biologi berbasis Inquiry Lab materi Sistem Gerak manusia terhadap kemampuan hasil belajar.

\section{Metode Penelitian}

Model penelitian dan pengembangan (Research \& Development) yang diterapkan mengacu pada tahapan menurut Borg \& Gall (1983) dengan tahapan sebagai berikut: 1) penelitian dan pengumpulan data, 2) perencanaan, 3) pengembangan produk awal, 4) uji coba lapangan awal, 5) revisi produk I, 6) uji coba lapangan utama, 7) revisi produk II, 8) uji lapangan operasional, 9) revisi akhir, 10) penyebaran dan implementasi. Dalam penelitian ini dapat menggunakan sampel yang tidak terlalu besar dan diperbolehkan mengembangkan sampai tahapan tertentu sesuai dengan kebutuhan peneliti (Emzir, 2012).

Studi lapangan dilakukan melalui observasi di SMA Negeri 1 Mejayan untuk mengetahui kondisi buku dan modul yang biologi yang digunakan dan informasi tentang materi yang sulit diserap siswa. Informasi terkait buku dan modul yang diperoleh mencakup isinya terdiri dari tujuan, materi, kegiatan, dan soal evaluasi.

Analisis buku dan modul di SMA Negeri 1 Mejayan dilakukan dengan cara menilai kesesuaian isi dengan indikator pembelajaran yang dikembangkan dari aspek Inquiry Lab dan dimensi pengetahuan melalui wawancara dengan guru, pemberian angket pendapat siswa. 
Subyek uji coba awal dilakukan oleh masing-masing satu orang ahli materi, ahli pengembang desain, Ahli perangkat. Data hasil uji validasi ahli berupa data kualitatif yang kemudian dianalisis secara deskriptif untuk dasar revisi draft modul. Kriteria penilaian dari Depdiknas (2008).

Tahap pengembangan modul awal berfokus pada kesesuaian karakteristik modul. Pengembangan modul memperhatikan model Inquiry Lab dan hasil belajar dilanjutkan dengan penentuan desain. Draft modul dilengkapi dengan perangkat pembelajaran yang mencakup silabus, Rencana Pelaksanaan Pembelajaran (RPP) dan instrumen penilaian yang mengacu pada aspek model Inquiry Lab.

Tahap uji coba lapangan awal validasi dilakukan oleh validator ahli materi modul, ahli validasi pengembangan desain, dan ahli perangkat pembelajaran. Hasil uji validasi ahli dianalisis secara deskriptif kualitatif untuk data pendapat dan saran serta deskriptif kuantitatif untuk analisis dapat dilihat ditabel 1.

Tahap uji coba lapangan terbatas dilakukan sebelum modul digunakan dalam skala lebih luas. Uji coba lapangan terbatas dilakukan oleh validasi perorangan praktisi pendidikan (guru Biologi) dan uji kelompok kecil (peserta didik).

Tabel 1. Pengambilan Keputusan Revisi (Suwastono,

\begin{tabular}{ccc} 
Tingkat & 2011) & \\
Pencapaian & Kualifikasi & Keterangan \\
\hline $81-100$ & Sangat Baik & Tidak Perlu \\
$61-80$ & Baik & Direvisi \\
$41-60$ & Cukup & Tidak Perlu \\
$21-40$ & Kurang Baik & Direvisi \\
$0-20$ & Sangat Kurang & Direvisi \\
& & Direvisi \\
& & Direvisi
\end{tabular}

Tahap uji coba lapangan terbatas dilakukan sebelum modul digunakan dalam skala lebih luas. Uji coba lapangan terbatas dilakukan oleh validasi perorangan praktisi pendidikan (guru Biologi) dan uji kelompok kecil (peserta didik).

Uji lapangan operasional dilakukan untuk mengetahui keefektivitasan produk berupa modul yang dibuat yaitu modul berbasis Inquiry Lab kelas pada materi Sistem Gerak yang diterapkan dalam kuasi eksperimen dengan penjelasan (Sugiyono, 2013) sebagai berikut :

Tabel 2 Desain Penelitian"Pretest-Postes Nonequivalent Control Group Desaign"

\begin{tabular}{lccc}
\multicolumn{4}{c}{ (Sugiyono, 2013) } \\
\hline \multicolumn{1}{c}{ Kelompok } & Pretes & Perlakuan & Postes \\
\hline $\begin{array}{l}\text { Kelas Modul Inquiry } \\
\text { lab }\end{array}$ & $\mathrm{O} 1$ & $\mathrm{X}_{1}$ & $\mathrm{O} 2$ \\
\hline Kelas Modul Sekolah & $\mathrm{O} 3$ & $\mathrm{X}_{2}$ & $\mathrm{O} 4$ \\
\hline
\end{tabular}

Keterangan:

$\mathrm{O} 1$ : pelaksanaan pretes kelas perlakuan

$\mathrm{O} 2$ : pelaksanaan postes kelas perlakuan

$\mathrm{X}_{1}$ : pembelajaran dengan modul Inquiry Lab

$\mathrm{X}_{2}$ : pembelajaran tanpa modul Inquiry Lab

O3 : pelaksanaan pretest kelas kontrol

O4 : pelaksanaan ppostest kelas kontrol

\section{Hasil Penelitian dan Pembahasan}

\section{a. Karakteristik Modul Inquiry Lab untuk meningkatkan Hasil Belajar}

Hasil dari penelitian pengembangan yang telah dilaksanakan berupa modul pembelajaran biologi berbasis Inquiry Lab pada materi sistem Gerak untuk meningkatkan kemampuan berpikir kritis.

Tahap penelitian dan pengumpulan data dalam pengembangan modul berbasis Inquiry Lab untuk meningkatkan hasil belajar mencakup beberapa tahap meliputi studi pustaka, studi lapangan, dan analisis kebutuhan.

Studi pustaka yang dilakukan meliputi modul, model pembelajaran Inquiry Lab, modul berbasis Inquiry Lab dan hasil belajar.

Studi lapangan yang dilakukan meliputi kegiatan observasi, wawancara dan pemberian angket. Tahap wawancara ditujukan kepada peserta didik dan guru mata pelajaran Biologi, sedangkan angket penguasaan kelompok materi Biologi dan observasi awal kemampuan berpikir kritis ditujukan kepada peserta didik.

Hasil observasi awal hasil belajar pada peserta didik di SMA Negeri 1 Mejayan dapat dilihat di Tabel 3. 
Tabel 3. hasil belajar siswa

\begin{tabular}{cccc}
\hline Kelas & $\begin{array}{c}\text { Jumlah } \\
\text { Siswa }\end{array}$ & $\begin{array}{c}\text { Tuntas } \\
(\boldsymbol{\%})\end{array}$ & $\begin{array}{c}\text { Tidak Tuntas } \\
(\boldsymbol{\%})\end{array}$ \\
\hline XIIPA1 & 34 & 68 & 32 \\
XIIPA2 & 35 & 64 & 36 \\
XIIPA3 & 35 & 64 & 34 \\
\hline
\end{tabular}

Berdasarkan Tabel 3 hasil belajar siswa menunjukan bahwa Berdasarkan hasil nilai MID semester SMA Negeri 1 Mejayan didapatkan data bahwa hasil belajar peserta didik masih rendah, dari 34 peserta didik, hasil belajar siswa hanya sebesar $68 \%$ yang mencapai KKM 77 dari hasil belajar siswa masih rendah karena 32\% hasil belajar siswa masih dibawah KKM.

Hasil observasi analisis 8 Standar Nasional Pendidikan (SNP) di SMA Negeri 1 Mejayan yang meliputi standar isi, standar proses, standar kompetisi lulusan, standar pendidik dan tenaga kependidikan, standar sarana dan prasarana, standar pengelolaan, standar pembiayaan dan standar penilaian dapat dilihat di gambar 1

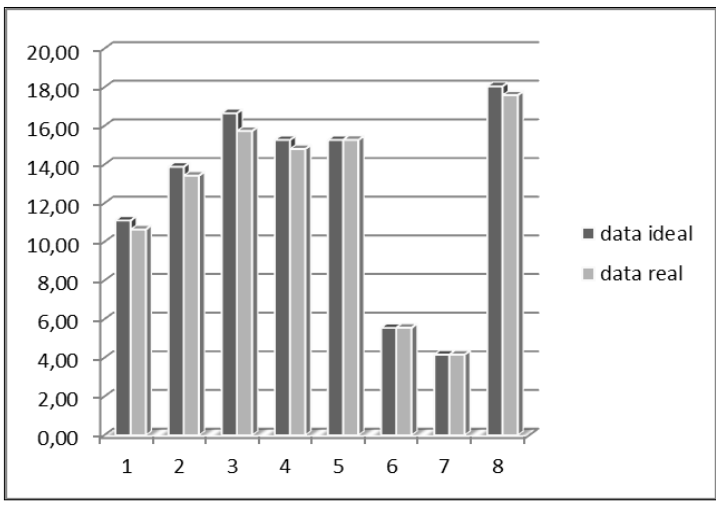

Gambar 1. Skor Implementasi 8 SNP di SMA Negeri 1 Mejayan

Hasil 8 SNP menunjukkan adanya ketercapaian sebesar 2,78 \%. Skor gap tersebut berasal dari beberapa komponen SNP yang memperoleh skor 1 dan 2 . Komponen standar proses memiliki gap $2.77 \%$. Standar proses berkaitan dengan aktifitas antara peserta didik dengan pendidik serta lingkunganya selama proses pembelajaran. Rendahnya standar proses dipengaruhi oleh kurang optimalnya proses pembelajaran yang berlangsung di dalam kelas.
Hasil persentase observasi pembelajaran biologi menunjukan bahwa komponen guru menduduki persentase paling rendah yaitu $58.25 \%$, sedangkan persentase paling tinggi komponen lingkungan yaitu $81 \%$. Presentase setiap komponen dapat di lihat di Tabel 4.

Tabel 4. Persentase Lembar Observasi Pembelajaran Biologi SMAN 1 Mejayan

\begin{tabular}{cccc}
\hline No. & Komponen & $\begin{array}{c}\text { Rata- } \\
\text { rata } \\
(\mathbf{\%})\end{array}$ & Persentase \\
\hline 1. & Peserta didik & 2.55 & 63.75 \\
\hline 2. & $\begin{array}{c}\text { Keterampilan } \\
\text { guru }\end{array}$ & 2.85 & 71.25 \\
\hline 3. & Materi & 2.83 & 70.75 \\
\hline 4. & Guru & 2.33 & 58.25 \\
\hline 5. & $\begin{array}{c}\text { Pengelolaan } \\
\text { Kelas }\end{array}$ & 2.83 & 70.75 \\
\hline 6. & Saran & 3.08 & 77 \\
\hline 7. & Lingkungan & 3.24 & 81 \\
\hline
\end{tabular}

Hasil wawancara dengan guru dan siswa terkait proses pembelajaran biologi adalah model atau metode yang digunakan guru dalam proses pembelajaran masih metode ceramah yang diselingi diskusi dan tanya jawab. Respon peserta didik terhadap model atau pembelajaran yang digunakan peserta didik kurang aktif, tidak memperhatikan, dan bosan. Bahan ajar yang digunakan kurang menarik perhatian peserta didik karena gambar tidak menarik dan tidak jelas, materi sangat sedikit dan tidak kompleks, tidak ada kegiatan dalam modul dan belum mengarahkan peserta didik untuk mendapatkan hasil belajar yang optimal.

Triyanto (2009), mengemukakan bahwa pembelajaran yang bermakna tidak akan terwujud jika siswa hanya mendengarkan ceramah dari guru. Guru biasanya menggunakan modul dan buku ajar yang berasal dari pasaran. Menurut Sungkono (2003), salah satu kompetensi yang perlu dimiliki seorang guru dalam melaksanakan tugasnya adalah mengembangkan bahan ajar. Hal tersebut diperkuat oleh pernyataan Depdiknas (2008), yang mengemukakan bahwa Permendiknas Nomor 16 Tahun 2007 
mengatur tentang standar kualifikasi akademik dan kompetensi guru, yaitu bagi guru pada satuan pendidikan jenjang SMA, baik dalam tuntutan kompetensi pedagogik maupun profesional berkaitan erat dengan kemampuan guru dalam mengembangkan sumber belajar dan bahan ajar.

Hasil pemberian angket pendapat secara umum guru peserta didik adalah belajar dengan cara hafalan, metode pembelajaran yang dilakukan oleh guru cenderung menggunakan metode ceramah, diskusi, dan tanya jawab, peserta didik tidak diwajibkan memiliki buku wajib pelajaran biologi, modul yang digunakan disekolah biasa dan kurang lengkap dan soal yang digunakan hanya sebatas C1-C3.

Hasil analisis Ujian Nasional (UN) Tahun Ajaran 2013/2014 pada materi Sistem Gerak khususnya, rata- rata skor yang diperoleh peserta didik SMA Negeri 1 Mejayan adalah 49,09, untuk tingkat Kota nilainya 55,95, dan untuk tingkat provinsi 33,97. (BSNP, 2013).

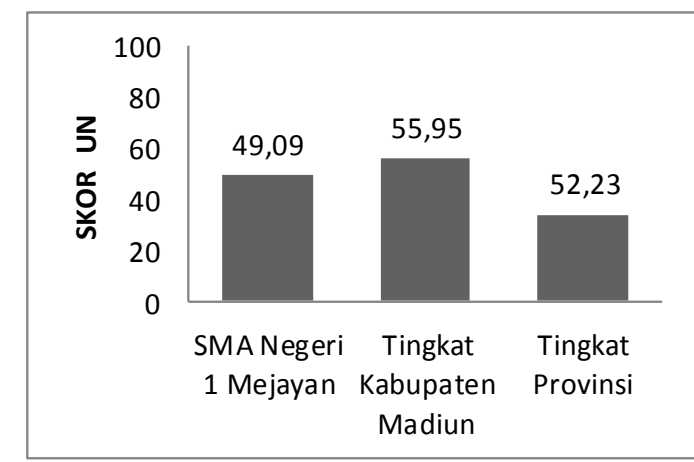

Gambar 2. Histogram Persentase Hasil UN 2013/2014 SMA Negeri 1 Mejayan

Analisis kebutuhan yang dilakukan meliputi analisis bahan ajar. Hasil analisis bahan ajar di SMA Negeri 1 Mejayan khususnya KD "Sistem Gerak" menunjukan bahwa isi buku hanya berisi kumpulan materi dan latihan soal-soal yang kurang meningkatkan hasil belajar materi sistem gerak manusia diperoleh 18,51 untuk indikator pengetahuan, Sikap sebesar 22,22 dan keterampilan sebesar 11,11.dapat dilihat ditabel 5.

Dari hasil analisi diatas bahwa mproses pembelajaran yang digunakan oleh guru biologi di SMA Negeri 1 Wera belum optimal meningkatkan hasil belajar siswa.

Data yang diperoleh pada tahap uji lapangan operasional meliputi data keterlaksanaan sintaks inkuiri terbimbing dan hasil belajar siswa. Hasil keterlaksanaan sintaks inkuiri terbimbing dan hasil belajar siswa secara rinci sebagai berikut.

Tabel.5.Keterlaksanaan sintak Inquiry Lab

\begin{tabular}{lccc}
\hline \multicolumn{4}{c}{ Keterlaksanaan Sintaks Inkuiri Terbimbing } \\
\hline $\begin{array}{l}\text { Sub } \\
\text { materi }\end{array}$ & Tulang (\%) & Sendi (\%) & Otot (\%) \\
\hline Rata-rata & 76.7 & 77.14 & 75.7 \\
& 0 & & 1 \\
\hline
\end{tabular}

Berdasarkan Tabel di atas menunjukkan bahwa keterlaksanaan sintaks Inquiry $L a b$ pada setiap sub materi ajar terjadi sedikit penurunan, diduga siswa mulai jenuh dengan pembelajaran yang menggunakan modul berbasis Inquiry Lab, karena siswa baru merasakan proses pembelajaran Biologi menggunakan modul dan model Inquiry Lab.

Sedangkan hasil belajar kognitif dilihat pada tabel 6:

Tabel.6. Hasil Pengetahuan Siswa

\begin{tabular}{lccccc}
\hline Kelas & $\begin{array}{c}\text { Ren } \\
\text { tang }\end{array}$ & $\begin{array}{c}\text { Nilai } \\
\text { mini- } \\
\text { mum }\end{array}$ & $\begin{array}{c}\text { Nilai } \\
\text { maksi- } \\
\text { mum }\end{array}$ & $\begin{array}{c}\text { Rata- } \\
\text { rata }\end{array}$ & $\begin{array}{c}\text { Stan- } \\
\text { dar } \\
\text { Devia- } \\
\text { si }\end{array}$ \\
\hline $\begin{array}{c}\text { Pretes XI } \\
\text { IPA 1 }\end{array}$ & 30 & 36 & 66 & 53,12 & 7,69 \\
$\begin{array}{c}\text { Postes XI } \\
\text { IPA 1 }\end{array}$ & 26 & 60 & 86 & 72,76 & 5,81 \\
$\begin{array}{c}\text { Pretes XI } \\
\text { IPA 2 }\end{array}$ & 43 & 30 & 73 & 55,11 & 9,94 \\
$\begin{array}{c}\text { Postes XI } \\
\text { IPA 2 }\end{array}$ & 33 & 43 & 76 & 60,82 & 7,73 \\
\hline
\end{tabular}

Berdasarkan Tabel diatas menunjukkan bahwa kelas XI IPA 1 (kelas kontrol) memperoleh rata-rata pretes yang rendah dibandingkan kelas XI IPA 2 (kelas eksperimen). Kesimpulkan bahwa kelas yang menggunakan model pembelajaran Inquiry $L a b$ memperoleh rata-rata pretes yang tinggi dibandingkan kelas yang menggunakan modul sekolah dan rata-rata postes lebih tinggi kelas XI MIA 2 (kelas 
eksperimen).

Ali (2007:135) menyatakan bahwa pembelajaran menggunakan modul lebih efektif dibandingkan pembelajaran konvensional, karena menggunakan modul siswa dapat belajar secara mandiri, sehingga siswa dapat mengembangkan langkah, kebutuhan, dan kemampuan dalam belajar yang berpengaruh pada hasil belajar siswa di kelas yang diterapkan pembelajaran menggunakan modul sebagai bahan ajar siswa.

\section{b. Kelayakan Modul Berbasis Inquiry Lab untuk Meningkatkan Hasil Belajar}

Tahap perencanaan disusun berdasarkan hasil tahap penelitian dan pengumpulan informasi. Tahap perencanaan digunakan sebagai dasar penyiapan rancangan awal penyusunan modul berbasis Inquiry Lab dan menyiapkan prosedur penelitian untuk uji kelayakan produk. Kegiatan yang dilakukan pada tahap perencanaan yaitu menyusun matriks, menentukan format modul berbasis Inquiry Lab, melakukan analisis kurikulum, menyusun tujuan pembelajaran, menentukan format perangkat pembelajaran yang digunakan, dan menentukan prosedur pengembangan modul ajar. Indikator hasil belajar.

Hasil pengembangan draft awal modul terdiri dari modul siswa dan modul guru. Untuk spesifikasi modul siswa yang dikembangkan meliputi judul, karateristik modul berbasis Inquiry Lab, pedoman penggunaan modul siswa, kegiatan pembelajaran yang berisi materi pembelajaran sistem gerak yang disesuaikan dengan sintaks Inquiry Lab, rangkuman materi, latihan soal tiap bab, uji kompetensi akhir, lembar penilaian diri, kunci jawaban, daftar pustaka dan glosarium.

Hasil validasi ahli materi modul siswa diperoleh nilai rata-rata tiap aspek sebesar $93.00 \%$ menunjukkan kualifikasi sangat baik dan dinyatakan tidak perlu direvisi. Menurut Mehrens (1984), strategi diartikan sebagai strategi yang mengacu kepada cara untuk membuat urutan dan mensintesis fakta, konsep, prosedur, dan prinsip-prinsip yang berkaitan.

Hasil validasi ahli pengembangan desain dan keterbacaan modul guru dan modul siswa diperoleh nilai rata-rata sebesar $82.90 \%$ yang menunjukkan kualifikasi sangat baik. Hal tersebut sesuai dengan pendapat Prastowo (2012), mengemukakan bahwa gambar-gambar yang dapat mendukung dan memperjelas isi materi sangat dibutuhkan karena selain memperjelas uraian materi, gambar atau simbol juga dapat menambah daya tarik, serta mengurangi kebosanan peserta didik untuk mempelajari modul.

Hasil validasi ahli perangkat pembelajaran diperoleh rata-rata semua aspek sebesar $95.70 \%$ yang menunjukkan kualifikasi sangat baik dan dinyatakan tidak perlu melakukan revisi. Berdasarkan hasil validasi ahli perangkat pembelajaran dan evaluasi modul guru dan modul siswa dapat disimpulkan bahwa tidak diperlukan revisi. Namun ada beberapa saran dari ahli seperti penyebaran soal di ratakan, latihan soal dikaitkan dengan kehidupan sehari-hari.

Hasil validasi guru diperoleh ratarata sebesar $92.00 \%$ menunjukkan kualifikasi sangat baik dan tidak perlu direvisi. Hasil uji kelompok kecil diperoleh rata-rata semua capaian sebesar $83.82 \%$ menunjukkan kualifikasi baik dan tidak perlu direvisi.

Hal tersebut sesuai dengan pendapat Prastowo (2012), mengemukakan bahwa gambar-gambar yang dapat mendukung dan memperjelas isi materi sangat dibutuhkan karena selain memperjelas uraian materi, gambar atau simbol juga dapat menambah daya tarik, serta mengurangi kebosanan peserta didik untuk mempelajari modul.

Ciri-ciri modul yang dianggap layak menurut Santyasa (2009), antara lain: 1) Didahului oleh pernyataan sasaran belajar; 2) Pengetahuan disusun sedemikian rupa, sehingga dapat menggiring partisipasi peserta didik secara aktif; 3) Memuat sistem 
penilaian berdasarkan penguasaan; 4) Memuat semua unsur bahan pelajaran dan semua tugas pelajaran; 5) Memberi peluang bagi perbedaan antar individu peserta didik; dan 6) Mengarah pada suatu tujuan belajar tuntas.

\section{c. Keefektivan Modul Berbasis Inquiry Lab untuk Meningkatkan Hasil Belajar}

Berdasarkan uji deskriptif statistik lelas yang menggunakan modul berbasis Inquiry $L a b$ memperoleh rata-rata pretes dan postes yang tinggi dibandingkan kelas yang menggunakan modul sekolah dapat dilihat di Tabel 6.

Berdasarkan hasil data di samping dapat dilihat adanya peningkatan hasil belajar siswa setelah pembelajaran pada kelas pelakuan lebih tinggi dari kelas modul sekolah. Nilai standar deviasi yang cukup besar (dari mean/rata-rata) menunjukkan adanya variasi yang cukup besar, begitu pula sebaliknya (Santoso, 2012). Kelas perlakuan nilai tertinggi pre-test 66 dan nilai terendah pre-test 36 dari nilai maksimal 100 sehingga memiliki rata-rata 72 dan standar deviasi 7 , nilai tertinggi post-test 90 dan nilai terendah post-test 65 dari nilai maksimal 100 sehingga memiliki rata-rata 76 dan standar deviasi 6. Kontrol memiliki nilai tertinggi pre-test 73 dan nilai terendah pre-test 43 dari nilai maksimal 100 dan memiliki rata-rata 60 , standar deviasi 9 , nilai tertinggi post-tes 76 dan terendah 43 dari nilai maksimal 100 sehingga memiliki rata-rata 60 dan standar deviasi Hal itu berarti bahwa rata-rata post-test yang tinggi pada kelas perlakuan dan standar deviasi yang mengindikasikan sebaran nilai siswa mendekati nilai rata-rata sehingga scaffolding yang diharapkan terlaksana.

Tabel 6. Hasil deskritif Statistik nilai pretest dan postest kelas XI IPA 1 Dan IPA

\begin{tabular}{|c|c|c|c|c|c|}
\hline Kelas & $\begin{array}{l}\text { Renta } \\
\text { ng }\end{array}$ & $\begin{array}{c}\text { Nilai } \\
\text { mini } \\
\text { mu } \\
\text { m }\end{array}$ & $\begin{array}{c}\text { Nilai } \\
\text { mak } \\
\text { simu } \\
\text { m }\end{array}$ & $\begin{array}{l}\text { Rata- } \\
\text { rata }\end{array}$ & $\begin{array}{c}\text { Stan- } \\
\text { dar } \\
\text { Devia- } \\
\text { si }\end{array}$ \\
\hline $\begin{array}{c}\text { Pretes } \\
\text { XI IPA } \\
1\end{array}$ & 30 & 36 & 66 & 53,12 & 7,69 \\
\hline $\begin{array}{c}\text { Postes } \\
\text { XI IPA } \\
1\end{array}$ & 26 & 60 & 86 & 72,76 & 5,81 \\
\hline $\begin{array}{c}\text { Pretes } \\
\text { XI IPA } \\
2 \\
\end{array}$ & 43 & 30 & 73 & 55,11 & 9,94 \\
\hline $\begin{array}{c}\text { Postes } \\
\text { XI IPA } \\
2\end{array}$ & 33 & 43 & 76 & 60,82 & 7,73 \\
\hline
\end{tabular}

berpikir kritis siswa dapat digunakan untuk mengetahui keefektifan pembelajaran menggunakan modul biologi berbasis inquiry Lab dengan perhitungan mennggunakan program SPSS 20 yang diawali oleh uji normalitas dan uji homogenitas.

Berdasarkan ringkasan mengenai hasil nilai kemampuan berpikir kritis siswa diketahui bahwa normalitas data yang diuji menggunakan Kolmogorov-Smirnov diperoleh taraf signifikasi pre-test sebesar 0,174 dan post-test 0,022 untuk nilai Kelas perlakuan dan diperoleh taraf signifikasi sebesar pre-test 0,200 dan post-test 0,133 untuk kelas modul sekolah, dan kedua nilai pre-test dan Post-test Kelas perlakuanKelas kontrol lebih besar dari $\alpha=0,05$, sehingga $\mathrm{H}_{0}$ diterima dan mempunyai arti nilai Kelas Modul-Kelas kontrol berdistribusi normal. Berdasarkan hasil uji homogenitas dengan taraf signifikasi sebesar pre-test 0,195 dan post-test 0,143 keduanya lebih besar dari $\alpha=0,05$, sehingga $\mathrm{H}_{0}$ diterima yang berarti variasi setiap sampel homogen.

perhitungan diperoleh hasil pre-test $=$ $0,585>\alpha=0,05$, sehingga $\mathrm{H}_{0}$ diterima. Data menunjukkan bahwa tidak terdapat perbedaan yang signifikan antara pre-test Kelas perlakuan dengan pre-test modul sekolah artinya kemampuan kedua kelas setara, dan perhitungan diperoleh hasil pretest $=0,000<\alpha=0,05$, sehingga $\mathrm{H}_{0}$ ditolak. Data menunjukkan bahwa terdapat perbedaan yang signifikan antara post-test 
Kelas perlakuan dengan kelas modul sekolah dengan rata-rata post-test kelas modul lebih tinggi berarti modul berbasis Inquiry $L a b$ efektif untuk meningkatkan kemampuan menganalisis siswa. Ali (2007:135) menyatakan bahwa pembelajaran menggunakan modul lebih efektif dibandingkan pembelajaran konvensional, karena menggunakan modul siswa dapat belajar secara mandiri, sehingga siswa dapat mengembangkan langkah, kebutuhan, dan kemampuan dalam belajar yang berpengaruh pada hasil belajar siswa di kelas yang diterapkan pembelajaran menggunakan modul sebagai bahan ajar siswa.

Tabel 7. Uji Anacova

\begin{tabular}{ccccc}
\hline Variabel & F & $\begin{array}{c}\text { Taraf } \\
\text { signifik } \\
\text { asi }\end{array}$ & $\begin{array}{c}\text { Partial } \\
\text { eta } \\
\text { Squared }\end{array}$ & $\begin{array}{c}\text { Kepu- } \\
\text { tusan }\end{array}$ \\
\hline Kelas & 50,22 & 0.000 & 0.432 & $\mathrm{H}_{0}$ \\
eksperime & & $(\mathrm{sig}<$ & & dito- \\
n, kontrol & & $0.05)$ & & lak \\
\hline
\end{tabular}

Hasil estimasi parameter menunjukan bahwa kelas kontrol yang tidak menggunakan modul berbasis Inquiry Lab mendapatkan nilai postest yang lebih rendah 11,93 dibanding kelas modul sekolah (Tabel 7).

Tabel 8. Parameter Estimasi Kelas Eksperimen

\begin{tabular}{cccc}
\hline Nilai & Kelas & Hasil & Sig \\
\hline \multirow{2}{*}{$\begin{array}{c}\text { Rata-rata } \\
\text { postest }\end{array}$} & $\begin{array}{c}\text { Kelas } \\
\text { eksperimen }\end{array}$ & 71,70 & - \\
\cline { 2 - 4 } & Kelas kontrol & 61,04 & - \\
\hline Estimasi & $\begin{array}{c}\text { Kelas } \\
\text { eksperimen }\end{array}$ & 11,93 & $0,00(<0,05)$ \\
\cline { 2 - 4 } & Kelas kontrol & 0,00 & - \\
\hline
\end{tabular}

Berdasarkan hasil uji coba lapangan operasional menunjukan bahwa kelas yang menggunakan modul berbasis Inquiry Lab efektif melatihkan kemampuan berpikir kritis peserta didik sebesar $51,7 \%$ dibandingkan kelas modul sekolah.

Menggunakan pembelajaran berbasis Inquiry Lab siswa dapat meningkatkan hasil belajar. Pernyataan ini sejalan dengan penelitian Berkmen, (2014) dalam yang menyatakan siswa terlibat dan dapat meningkatkan hasil belajar siswa di dalam kursus laboratorium saat mereka memiliki kesempatan untuk merancang dan melakukan inquiry berbasis eksperimen yang dapat menghasilkan suatu hasil yang baru. Sejalan dengan penelitian Nuangchalerm dan Thammasena (2009) yang menyatakan bahwa kegiatan pembelajaran berbasis penyelidikan dapat dipromosikan siswa baik dari segi kognitif, analitis, berpikir, dan kepuasan belajar. Harus disarankan untuk persiapan pedagogis dan memasukkan ke dalam kurikulum sains.

Pembelajaran dengan berbasis Inquiry Lab dapat membuat siswa lebih aktif dalam pembelajaran di kelas, sejalan dengan penelitian dari Hanson (2000) yang menyatakan penting, ditemukan bahwa siswa dalam kelompok inkuiri yang memiliki pengalaman dalam mengajukan pertanyaan di laboratorium kimia mengungguli kelompok kontrol dalam kemampuan mereka baik pertanyaan maupun lebih banyak lagi. Pembelajaran dengan berbasis Inquiry Lab lebih menyenangkan, sejalan dengan penelitian Prasart, (2013) menyatakan bahwa pembelajaran laboratorium lebih menarik dan menyenangkan serta dapat meningkatkan penilaian siswa.

Pembelajaran menggunakan berbasis Inquiry Lab dapat menghubungkan antara teori dan eksperimen. Sejalan dengan penelitian dari Waters (2012) yang menyatakan bahwa inkuiri berbasis labolatorium dapat membuat siswa menjembatani kesenjangan antara teori dan praktek, menggambarkan materi yang diajarkan di kuliah, meningkatkan antusiasme dan mendorong sikap ilmiah, dan untuk mengembangkan keterampilan observasi, penalaran dan berpikir kritis.

\section{Kesimpulan dan Rekomendasi}

Kesimpulan yang diperoleh dari penelitian dan pengembangan modul berbasis Inquiry Lab pada materi Sistem Gerak adalah:

Produk modul berbasis Inquiry Lab untuk meningkatkan kemampuan berpikir 
kritis pada materi sistem gerak kelas XI SMA Negeri 1 Mejayan dikembangkan sesuai prosedur pengembangan Borg and Gall yang dimodifikasi menjadi 9 tahapan, dengan menggunakan sintaks Inquiry Lab dan indikator berpikir kritis Fascione Karakteristik Modul Biologi Inquiry Lab pada Materi Sistem Gerak yang dikembangkan menggunakan sintak Inquiry Lab meliputi observasi, manipulasi, generalisasi, verifikasi dan aplikasi serta enam aspek berpikir kritis yaitu Interprestasi, analisis, evaluasi, kesimpulan, penjelasan dan pengaturan diri. Setiap kegiatan pembelajaran siswa di arahkan untuk menemukan konsep melalui aktivitas laboratorium yang divisualisasikan pada tujuan, materi, kegiatan, dan soal evaluasi.

Kelayakan modul berbasis Inquiry Lab untuk meningkatkan kemampuan berpikir kritis pada materi sistem gerak kelas XI SMA Negeri 1 Mejayan telah diuji melalui uji validasi ahli, validasi praktisi pendidikan, uji kelompok kecil dan uji lapangan operasional berkualifikasi baik sampai dengan sangat baik.

Modul berbasis Inquiry Lab efektif untuk memberdayakan kemampuan berpikir kritis pada materi ajar sistem Gerak dibandingkan kelas yang menggunakan modul sekolah kelas XI SMA Negeri 1 Mejayan karena menunjukkan nilai postes dengan nilai sig $=0.0000<\alpha 0.05$

\section{Daftar Pustaka}

Ali, Muhammad. 2007. Guru dalam Proses Belajar Mengajar, Bandung : Percetakan Sinar Baru

Berkmen, M.B., Murthy, C.A., and Broulidakis, M.P.. (2014) An Inquiry-Based Laboratory Module to Promote Understanding of the Scientific Method and Bacterial Conjugation.

Borg, W.R., Gall, M.D. 1983. Educational Research an Introduction (Revision Edition). USA: Von Hoffman Press.

BSNP. 2013. Laporan Hasil Ujian Nasional. Jakarta: Puslitbang Kemdikbud.
Depdiknas. 2008.Standar Penilaian Buku Pelajaran Sains. Jakarta: Pusat Perbukuan.

Emzir. 2012. Metodologi Penelitian Pendidikan: Kualitatif dan Kuantitatif. Jakarta : Raja Grafindo Persada.

Gagne, R. 1980. Learnabel Aspects of Human Thinking. New York: The Eric Science, Mathematics and Environmental Education Clearing House .

Galbreath, J. 1999. Preparing the 21st Century Worker : The Link Between Computer Based Technology and Future Skill Sets. Educational Technology, 39 (6): 4-22.

Hanson, D., Wolfskill, T. 2000. Process Workshop-A New Model for Instruction. Journal of Chemical Educatiuon, 75(1) : 120-130.

Johnson, L., Adams, S. 2011. Inquiry Lab: The Report from the Implementation Project. Texas: The New Media Consortium.

Johnson, L., Smith, R., Smythe, J., et al. Johnson, L., Smith, R., Smythe, J., et al. 2009. Challenge-Based Learning: An Approach for Our Time. Austin, Texas: The New Media Consortium.

Prasart Nuangchalerm dan Benjaporn Thammasena (2009). Cognitive Development, Analytical Thinking and Learning Satisfaction of Second Grade Students Learned through InquiryBased Learning

Prastowo. 2012. Panduan Kreatif Membuat Bahan Ajar Inovatif. Yogyakarta: Diva Press.

Ricketts, J.C., Rudd, R.D. 2005. Critical Thinking Skills Of Selected Youth Leaders: The Efficacy Of Critical Thinking Dispositions, Leadership, And Academic Performance. Journal of Agricultural Education, 46, (1).

Sugiyono. 2013. Metode Penelitian Pendidikan. Bandung : Alfabeta.

Santyasa, I.W. 2009. Metologi Penelitian Pengembangan dan Teori Pengembangan Modul. Makalah disajikan dalam penelitian bagi SD, 
SMP, SMA, dan SMK di Kecamatan Nusa Penida Kabupaten Klungkung, 12-14 Januari 2009.

Suryadi. 2005. Penggunaan Pendekatan Pembelajaran Tidak Langsung Serta Pendekatan Gabungan Langsung dan Tidak Langsung dalam Rangka meningkatkan Kemampuan Berpikir Matematika Tingkat Tinggi Siswa SLTP. Tesis tidak diterbitkan. Bandung :SPS UPI.

Snyder, L.G., Snyder. M.J. 2008. Teaching Critical Thinking and Problem Solving Skills. The Delta Epselon Journal, 50 ( 2): 90-99.

Stobaugh, R. 2013. Assessing Critical Thinking in Elementary School Meeting the Common Core. New York: Routledge.

Swiden, C.L. 2013. Effects Of Inquiry Lab On Student Motivation And Achievement. Montana : Montana State University

Vajoczki, S., Watt, S., Vine, M.M., Liao, Xueqing (Rose). 2011. Inquiry Learning : Level, Discipline, Class Size, What Matters?. International Journal for the Scholarship of Teacing and Learning. Volume 5(1).

Waters, Norman C. (2012) The Advantages of Inquiry-Based Laboratory Exercises within the Life Sciences.

Wenning, 2010 \& Khan 2011. "Sample Learning Sequences Based on The Levels of Inquiry Model of Science Teaching. 